\title{
The Role of Traditional Media in a Converging Media World
}

\author{
Ingela Wadbring
}

Invited to a panel with the title Nordic Media Systems: Worth Defending, Worth Developing, Worth Exporting? as a researcher with focus on the newspaper market, the answer to the question in the panel headline was not obvious. Are the Nordic newspapers worth defending, developing and exporting? Is there a specific Nordic newspaper market? Is the newspaper market the part of the media system that is most important to defend, develop and export?

The newspaper market in all the Nordic countries - as well as in other countries in the Western world - has undergone a transformation since around the turn of the century, concerning technical development, business models, status in the public sphere and so on. The transformation for the newspaper industry has been harder than for any other media form because of the unsustainable business models. To be specific: Advertisers turn to other media forms, preferably online, and the subscribers leave the printed papers and turn online to find the news, usually free of charge (Ohlsson 2015; Reuters Institute Digital News Report 2016 2016). Simultaneously, the newspaper companies in the Nordic countries are strong providers of news online, especially the tabloids (Syvertsen et al. 2014), and the local morning papers are still the main suppliers of content to the national media companies (Lund et al. 2009). The traditional newspaper companies are also the main news providers in social media (Wadbring \& Ödmark 2015). The problem for the newspaper industry is declining revenue and the increasingly tough competition, but the newspaper business as a part of the media system is definitely of importance, worth defending and developing. It is however unclear if it is worth exporting.

Reflecting on the challenges the media market in general meets, I ended up drawing the conclusion that if we have something in the Nordic media systems that is worth defending, developing and exporting, it is not the newspaper industry: it is public service. In a market-oriented, globalised world, where old and new as well as private and public media actors compete online, public service is challenged both from the economical and the political spheres in society. In a time of convergence and increased competition, voices are raised in order to restrict the development of public service online, as well as to reduce public services' mission as broadcasters. A lot of research proves the importance of public service both as institution and idea, and for example the Baltic countries 
already approach the Nordic countries regarding public service (norden.lv 2016). The non-commercial, Nordic public service is therefore the part of the media system that is worth defending, developing and exporting. I will outline my argumentation below.

There is also another question that I find important to raise in the context of Nordic media systems as well as in the context of the NordMedia conference. In society, as well as in the media industry in general, a lot of opinions are floating around about the role of public service (and of course other phenomena). Some of these opinions are well informed, others are purely ideological, and some are only suppositions. If we, as researchers, have research results that are of importance for the media system and the media development, it is necessary to have a dialogue with the rest of society and the media industry about these research results. No one is served by delusions floating around if we have answers on pressing questions. I would therefore like to say a few words also about the relation between the media industry/society and the academy.

Both questions I outline below are at least partly normative. For me, the first question is normative from the point of view that media, and especially news and fact-based content, is of importance in a democratic society. It is of importance that the citizens are informed about current affairs, and that it is possible to find quality journalism without having to be charged for it. Public service here has advantages over other media forms. The second question, about a dialogue between the industry and the academy, is also normative in the sense that there is a responsibility from both sides: to listen, learn, discuss and be generous.

\section{Public service as a significant actor in society}

Why then is public service radio and television in all its forms so important, worth defending, developing and maybe exporting? There are several reasons. In this short article I will briefly outline some of the arguments. The arguments are not new, or revolutionary. Everyone interested in media policy has heard them before, but they are nevertheless of relevance. In several areas, public service media (PSM) can do things that commercial media cannot (for overviews, see Newton 2015; Lowe \& Martin 2014; Lowe \& Yamamoto 2016):

- PSM can be held responsible for media variety

- PSM can be held responsible for impartiality and objectivity

- PSM can be held responsible for developing programmes for cultural minorities, children, etc., and also for developing programmes for small language markets

- PSM, in terms of television, is the most important medium regarding news use - not in terms of depth, but in terms of usage, and especially among people who are not specifically interested in news

- In a crisis, PSM still have a unique position, in its traditional form or online - even among young people

- People generally have high confidence in PSM

- Societies with strong PSM have a high level of general trust among the inhabitants. 
The list could be longer, but I do not think it is necessary for my purpose. Few commentators want to close down public service. The most important questions discussed are about the width of PSM content, and the degree of PSM's development online (Allmenkringkastingsrapporten 2015; Nord \& Grusell 2012; Public service-kommissionen 2016). Even the strongest critics usually agree that PSM is necessary in society - but in another, usually more limited, way than today. Both questions above (the width and degree of online development) are actually about market disruptions. That implies that the media market is regarded as a commercial market. However, PSM as well as other media are also part of a democratic market. As such, arguments other than market disruptions must be of interest.

\section{PSM broad and online}

A broad PSM is probably necessary if one wants to encourage people to find their way to its content. Programmes like the Eurovision song contest might not be important concerning content, but it is still a campfire in families, also for young peoples. If we find public service important, it is necessary to exhibit a rich and diversified menu. The responsibility that PSM have in societies like the Nordic ones is an institutional responsibility.

It is also necessary that PSM - with its specific financing - can be able to develop online and compete with the commercially financed media. Some commentators mean that PSM have such an impact on a free market (read: the newspaper industry), that they hinder the commercially financed media and make it impossible for them to charge for their content. Others identify Google and other global companies as more problematic for the local and national markets (read again: the newspaper industry). This question is under investigation in Denmark in 2016-2017 (Slots- og Kulturstyrelsen 2016), and the results will be of great interest in all Nordic countries.

In my opinion, PSM must be able to develop online. Otherwise it would be a one-way competition, since other media companies invest in video online as well as specific TVchannels, in viral material to obtain clicks, put all the content from the original media form online etc. Online must be a place where PSM and commercial media can meet, and where text, sound and video also can meet. Online cannot equal "commercial only".

If PSM should not be allowed to meet the competition from other types of media, they will probably die a slow, or maybe even rapid, death. Young people will never be attracted to linear television. On-demand television, new formats, specific online formats and other online activities are necessary for PSM to survive the generational digital shift that is going on right now. The development must be from public service broadcasting to public service media, and I therefore consistently use the concept PSM, not PSB, in this argumentation.

To conclude, public service media may be more important than ever before, in the commercialised and globalised societies we live in. It is one of the last bastions not creating content to receive revenues, but to promote content for its own sake. That is worth defending, developing and exporting. 


\section{The relation between the academy and industry}

The second issue I would like to address is the relation between the media industry and research. I am convinced that media research can be helpful in developing the Nordic media system in general, but I am not sure that we will be invited to a discussion about that. I am also not sure that researchers have an obvious interest in being a party in such a relation.

First, if scholars conduct research that is of no relevance for the industry, we will have a problem as researchers. We need to do both basic and applied research. We also need to report about research in different ways to reach out. If we as researchers only conduct research about very limited questions that fit in international journals, i.e. approximately 7,000 words, we are not able to take a part in a discussion about whole media systems. It is necessary with broader approaches, and thus also broad knowledge among researchers. The progress we face today, towards research specialisation, has its advantages, but also its limitations. Media systems and media policy need generalists alongside specialists.

Second: If the industry does not find research and researchers useful and reliable, the industry will have a problem. Too many decisions in the media industry are taken without facts and reliable data, and sometimes I feel that something like contempt can be found among media industry representatives towards media researchers, and that this has increased in recent years. Let me give you a few examples:

1. I met a former editor-in-chief at one of the big newspapers in Sweden and discussed how they use research in decision-making. She smiled, shook her head, and said: "Research? Texts over two pages no one [wants to] read. We don't know where to find research and don't have time to look for it. We use our gut feeling."

2. I was invited to a rather big meeting with CEOs and editors-in-chiefs to discuss a possible cooperation. The meeting ended in nothing, since we researchers were accused of being formalistic and old fashioned when we wanted to start with a research problem to be solved, instead of building a permanent workshop with possibilities to conduct experiments. Researchers were also accused of always being historians: "All research is old already when it is published."

3. In blogs and editorials written by CEOs and editors-in-chief, it is sometimes obvious that they consider themselves as knowing more than researchers about almost everything concerning research: methodological questions, causal explanations, etc. in a way I find provoking. I see and hear very much anecdotal evidence of this.

This problem must be addressed in different ways. (1) We as researchers must be better at making our findings accessible to the industry: international journals are not the way for this (but the way for spreading research globally, which of course also is important). (2) We must also help the media industry understand how we can be a part of development and decision-making. They will not come and ask us. (3) We - at least some of us - must be interested in doing this.

There are successful co-operations out there: NxtMedia in Norway, Next Media in Finland (ended in 2014) as well as the fledgling Media Arena in Sweden, all started 
as industry initiatives. I hope that researchers will be invited and participate in these initiatives, in order to defend, develop and maybe even export applied research. I also hope that researchers will accept the invitations.

\section{Some final words}

I am worried about a future media market, characterised by a weak and narrow public service. I am also worried about the situation for the newspaper market. The newspaper companies have to date taken an almost public service responsibility (as idea) on their local market, but since many of them are having serious problems, the future does not look bright. I am worried about a strong(er) commercialisation on the general media market, with more entertainment and less substantial content. It is my conviction that a dual system is good for democratic societies. We all need access to a balanced media diet, and the market itself cannot provide that. The market must be regarded as both a commercial and a democratic arena.

I am also worried about the almost absent relation between the media industry and the academy. Actors outside the traditional media industry are not tied to traditions, do not always behave responsibly and it is still the traditional media - not only PSBs - which are of importance in society, since they are the main (news/fact) content deliverers offline as well as online. I am convinced that media researchers can contribute to a fruitful and sustainable development - if we are allowed to participate, and if we want to participate.

On the other hand, I am also optimistic. It has never been as exciting to be a media researcher as now.

\section{References}

Allmenkringkastingsrapporten 2015 [The public broadcasting report 2015.] (2016). Oslo: Medietilsynet.

Lowe, Gregory Ferrell \& Yamamoto, Nobuto (eds.) (2016). Crossing Borders and Boundaries in Public Service Media. RIPE 2015. Gothenburg: Nordicom.

Lowe, Gregory Ferrell \& Martin, Fiona (eds.) (2014). The Value of Public Service Media. RIPE 2013. Gothenburg: Nordicom.

Lund, Anker Brink; Willig, Ida \& Blach-Ørsten, Mark (2009). Hvor kommer nyhederne fra? Den journalistiske fødekæde i Danmark før og nu. [Where Do the News Come From? The Journalistic Food Chain in Denmark Then and Now.] Århus: Forlaget Ajour.

Newton, Ken (2016). Public Service and Commercial Broadcasting: Impacts on Politics and Society. The Political Quarterly, 87(1): 31-38.

Nord, Lars \& Grusell, Marie (2012). Inte för smalt, inte för brett. Spelet om framtidens public service. [Not too narrow, not too broad. The game about public service in the future.] Gothenburg: Stiftelsen etermedierna och Nordicom.

norden.lv (2016). The Nordic-Baltic Media Meeting in Riga. [News item, undated]. http://norden.lv/en/ [Accessed 10 July 2016].

Ohlsson, Jonas (2015). The Nordic Media Market. Göteborg: Nordicom.

Public service-komissionen (2016). Framtidens public service - från analog institution till digital funktion. [Public service in the future - from analogue institution to digital function.] http://www.publicservicekomissionen.se. [Accessed 20 May 2016].

Reuters Institute Digital News Report 2016 (2016). Oxford: Reuters Institute for the Study of Journalism.

Slots- og Kulturstyrelsen (2016). Internationale aktørers betydning for det danske mediemarked skal undersoeges [News item 14 June 2016]. http://slks.dk/ [Accessed 21 July 2016].

Syvertsen, Trine; Enli, Gunn; Mjøs, Ole J. \& Moe, Hallvard (2014). The Media Welfare State: Nordic Media in the Digital Era. Ann Arbor, MI: University of Michigan Press.

Wadbring, Ingela \& Ödmark, Sara (2015). From Kittens to Racism: News Sharing and Shared News in Social Media. Paper presented at the NordMedia Conference in Copenhagen, August 2015. 